\title{
Antioxidant Defense System Alternations in Four Crab Species as a Bio-Indicator of Environmental Contamination
}

\author{
Aderonke Omolara LAWAL-ARE ${ }^{1}$, Rasheed Olatunji MORUF²*, Sarah Oyeyinka OLUSEYE-ARE ${ }^{1}$, Tajudeen \\ Opeyemi ISOLA ${ }^{3}$ \\ ${ }^{1}$ Department of Marine Sciences,University of Lagos, Akoka,Lagos, Nigeria \\ ${ }^{2}$ Department of Fisheries and Aquaculture, Bayero University, Kano, Nigeria \\ ${ }^{3}$ Department of Veterinary Public Health and Preventive Medicine, University of Ibadan, Nigeria \\ *corresponding cuthor: tunjimoruf@gmail.com, Phone: +234-8022429983
}

Bulletin UASVM Veterinary Medicine 76(1)/2019

Print ISSN 1843-5270; Electronic ISSN 1843-5378

doi:10.15835/buasvmcn-vm: 2019.0001

\begin{abstract}
The ecological health status of aquatic environment is a determinant for the survival and growth of organisms within such niche. An investigative study was carried out on four crab species - Cardiosoma armatum, Goniopsis pelli, Callinectes amnicola, Portunus validusinhabiting contaminated sites in Lagos Lagoon- exploring their antioxidant defense mechanism in the light of heavy metal concentration in the crab tissues. Amongst the measured heavy metals, cadmium level proved to be significantly highest $(\mathrm{P}<0.05)$ with range concentration of $0.42 \pm 0.12 \mathrm{mg}$ / $\mathrm{kg}$ (G. pelli) $-0.79 \pm 0.06 \mathrm{mg} / \mathrm{kg}$ (C. armatum). Contrastingly, lead was marginally low with concentration below 0.01 $\mathrm{mg} / \mathrm{kg}$ in all the crab species. Organismal responses to environmental pollution showed a high level of biomarkers. C. armatum was observed to have elevated level of superoxide dismutase $(123.04 \pm 0.01 \mathrm{~min} / \mathrm{mg} / \mathrm{pro})$, catalase $(7.74 \pm 0.05 \mathrm{~min} / \mathrm{mg} / \mathrm{pro})$, glutathion transferase $(18.21 \pm 0.02 \mathrm{Hmol} / \mathrm{mg} \mathrm{pro})$, reduced glutathione $(2.92 \pm 0.04 \mathrm{Hmol} /$ $\mathrm{mg}$ pro) and glutathione peroxidase $(61.85 \pm 0.06 \mathrm{Hmol} / \mathrm{mg} \mathrm{pro})$ above other species with C. amnicola recording the lowest concentration of the biomarkers. With the low level of heavy metals and corresponding high concentration of these biomarkers, the pollution indices within the study habitat are quite modest.
\end{abstract}

Keywords: brachyuran, ecosystem, heavy metal, antioxidant, Lagos Lagoon.

\section{Introduction}

Crabs have flourished predominantly in the invertebrate fauna because of its ubiquitous existence in almost all part of the world oceans, fresh water, and even on land (Akin-Oriola et al., 2005). Many species actively forage on land and several species have become semi-terrestrial (Cumberlidge, 1999; Moruf and Ojetayo, 2017). The marine littoral ecosystem and estuaries are threatened by increasing levels of various pollutants originating from human activities, urban, agricultural and industrial discharges. Heavy metals are potent toxicants which have a wide spectrum of adverse effects on different levels of organismic integration. They accumulate in the bodies of organisms and increase the formation of reactive oxygen species (ROS) which can lead to protein, DNA, and lipid damage (Frenzilli et al., 2001; Regoli et al., 2004), enzyme inhibition, cell signalling impairment, disruption of calcium homeostasis, and changes in gene regulation (Elbekai and ElKadi, 2005).

The assessment of biological effects of chemicals, from molecular to tissue levels, has been considered as an effective biological tool 
in the bio monitoring of marine ecosystem contamination (Jebali, et al., 2012). Biological monitor or pollution biomarker is early diagnostic tool for biological effect measurement and environmental quality assessment and algae, macro-invertebrates and fish are considered as important indicators (Mandaville, 2002, Gadzała-Kopciuch et al., 2004). Biomarkers are measurements in body fluids, cells or tissues indicating biochemical or cellular modifications due to the presence and magnitude of toxicants, or of host response (Maharajan and Shanmugavel, 2015). Examples include superoxide dismutase (SOD), catalase (CAT), glutathione transferase (GT), glutathione peroxidase (GPx), reduced glutathione (GSH) and lipid peroxidation (LPx). They are used after exposure to environmental or anthropogenic sources of pollution, to elucidate cause-effect and dose-effect relationships in health risk assessment, in clinical diagnoses and for monitoring purposes. Generally, biomarker responses are considered to be intermediates between pollutant sources and higher-level effects (Suter, 1990). When these compensatory responses are activated, the survival potential of the organism may already have begun to decline because the ability of the organism to mount compensatory responses to new environmental challenges may have been compromised (Depledge, 1993). The most compelling reason for using biomarkers is that they can give information on the biological effects of pollutants rather than a mere quantification of their environmental levels.

The antioxidants enzymes such as catalase, SOD and GPx are the primary enzymes of the antioxidant defense against oxidative damages generated by multiple environmental stressors and have been studied in fish and shellfish species (Vijayavel et al., 2004; Martin Diaz et

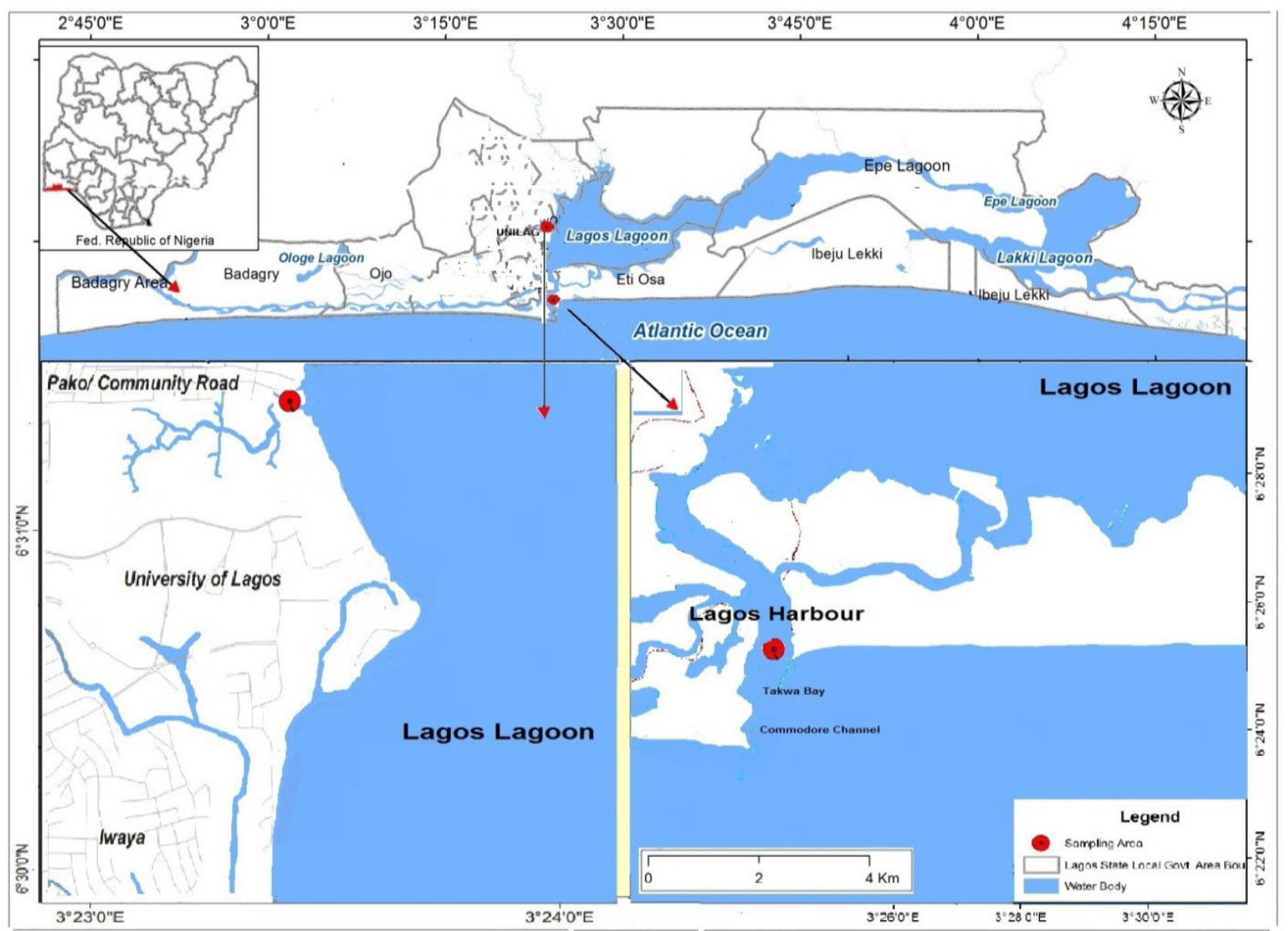

Figure 1. Map of the Lagos Lagoon showing sampling sites 
al., 2005; Usese et al., 2018). Their induction reflects a specific response to variable pollutants including hydrocarbons and metals (El-Khayat et al., 2015). In addition, malonedialdehyde (MDA) is a biomarker of oxidative damage that reflects the state of lipid peroxidation of the membranes of many living organisms (Lykkesfeldt, 2007). The main aim of the present study was to use chemical biomarkers to evaluate the health status of Cardiosoma armatum, Goniopsispelli, Callinectes amnicola and Portunus validus inhibiting contaminated locations in the Lagos Lagoon ecosystem.

\section{Materials and Methods Study site}

The Lagos Lagoon $\left(3^{\circ} 10^{\prime} \mathrm{E}\right.$ and $3^{\circ} 45^{\prime} \mathrm{E}$ and $6^{\circ} 15 \mathrm{~N}$ and $6^{\circ} 36^{\prime} \mathrm{N}$ ) is a part of the continuous system of lagoons found along the coast of Nigeria from the border of the Republic of Benin to NigerDelta (Lawal-Are and Owolabi, 2012; Akinjogunla and Moruf, 2018). The influx of seawater gives rise to brackish conditions in the lagoon and thus encourages the growth of mangroves (Emmanuel et al., 2010). The lagoon serves as a sink receiving large quantities of domestic and industrial wastes with implication for environmental degradation. The highly populated western axis of the Lagos Lagoon is fringed by mangrove swamps. Selection of study sites (Figure 1) was based on increasing anthropogenic effects from heaps of domestic and solid waste dumps.

\section{Sample Collection}

The mangrove crab species (Goniopsis pelli and Cardiosoma armatum) - were collected at the mudflats area of the Lagos Lagoon along Abule-Eledu refuse site using the removal method by hand picking. The fishing of the swimming crab species (Callinectes amnicola and Portunus validus) was done using circular lift nets at depth of $1-2.5 \mathrm{~m}$. The description and design characteristics of the circular lift nets were documented by Solarin et al. (2003). Approximately 30 adult crabs each of the crab species were collected over a twelveweek period (March-May, 2018). Crabs were immediately placed in styrofoam boxes and were transported to the Aquatic Toxicology and Ecophysiology laboratory at the Department of Marine Sciences, University of Lagos for proper identification, processing and analysis.

\section{Laboratory Analysis \\ Heavy metal levels in tissues of the crabs}

Muscle tissues of the examined samples were oven dried at $70^{\circ} \mathrm{C}$ for $1 \mathrm{hr}$ and ground to powder in ceramic mortars and $0.5 \mathrm{~g}$ of each sample were made into paste by adding double distilled water. This was followed by digestion using $5 \mathrm{ml}$ of $1 \mathrm{M}$ $\mathrm{HNO}_{3}$ and mild heat until brown fumes appeared, following an established technique (Don-Pedro et al., 2004). The samples were cooled off, made up to $50 \mathrm{ml}$ in a standard volumetric flask which have been subjected to acid wash to remove any trace of residual metals and then filtered. Thereafter, processed samples were analysed using Atomic Absorption Spectrophotometer (Perkin Elmer series) to determine levels of selected heavy metals (zinc, copper, cobalt, lead and cadmium).

\section{Evaluation of defense responses}

Excised muscle tissues of the crabs stored at $-20{ }^{\circ} \mathrm{C}$ were later thawed and homogenized for the assays of superoxide dismutase, catalase, glutathione transferase, reduced glutathione and glutathione peroxidase, following the protocol described by Lushchaks et al. (2005) and Bertholdo-Vargas et al.(2009). Protein was determined spectrophotometrically using the BioRad DC protein assay kit (Richmond, CA, USA) with bovine serum albumin (BSA) as a standard, based on the method of Lowry et al. (1951).The activity of SOD was determined by measuring the inhibition of auto-oxidation of epinephrine at $\mathrm{pH} 10.2$ at $30^{\circ} \mathrm{C}$. Three milliliters of $\mathrm{Na}_{2} \mathrm{CO}_{3}$ buffer was added to $0.02 \mathrm{ml}$ tissue homogenate (Tris- $\mathrm{HCl}$ buffer, $\mathrm{pH}$ 7.5) and treated with $0.03 \mathrm{ml}$ epinephrine reagent and centrifuged at room temperature for $10 \mathrm{~min}$ at $3,000 \mathrm{rpm}$. The clear supernatant was transferred into a $1.5 \mathrm{ml}$ cuvette, and the absorbance was measured against a reference blank at $480 \mathrm{~nm}$ using a spectrophotometer. The activity of CAT was determined following the absorbance of hydrogen peroxide at $240 \mathrm{~nm}, \mathrm{pH} 7.0$ and $25^{\circ} \mathrm{C}$.

GSH activity was determined by adding three milliliters of $10 \%$ trichloroacetic acid to $3 \mathrm{ml}$ homogenate and centrifuged at 3,000 rpm for 10 min. Then, $1.0 \mathrm{ml}$ of the supernatant was treated with $0.5 \mathrm{ml}$ Ellman's reagent and $3.0 \mathrm{ml}$ phosphate buffer $(0.2 \mathrm{M}, \mathrm{pH} 8.0)$ before the absorbance was read at $412 \mathrm{~nm}$ using a spectrophotometer. Glutathione-S-transferase (GST) activity was determined by adding into triplicate wells, $20 \mathrm{lL}$ of sample, $150 \mathrm{lL}$ of assay buffer $(100 \mathrm{mM}$ potassium 
Table 1. Mean heavy metal concentrations $(\mathrm{mg} / \mathrm{kg})$ in crab tissues

\begin{tabular}{lcccc}
\hline Metal (mg/Kg) & $\begin{array}{c}\text { Cardiosoma } \\
\text { armatum }\end{array}$ & $\begin{array}{c}\text { Goniopsis } \\
\text { pelli }\end{array}$ & $\begin{array}{c}\text { Callinectes } \\
\text { amnicola }\end{array}$ & $\begin{array}{c}\text { Portunus } \\
\text { validus }\end{array}$ \\
\hline \multirow{2}{*}{ Zinc } & $(0.42-0.63)$ & $(0.19-0.54)$ & $(0.44-0.51)$ & $(0.40-0.43)$ \\
& $0.53 \pm 0.06^{\mathrm{a}}$ & $0.31 \pm 0.12^{\mathrm{b}}$ & $0.48 \pm 0.02^{\mathrm{c}}$ & $0.41 \pm 0.01^{\mathrm{c}}$ \\
\hline \multirow{2}{*}{ Copper } & $(0.20-0.41)$ & $(0.11-0.46)$ & $(0.11-0.32)$ & $(0.42-0.63)$ \\
& $0.31 \pm 0.06^{\mathrm{a}}$ & $0.23 \pm 0.12^{\mathrm{b}}$ & $0.22 \pm 0.06^{\mathrm{b}}$ & $0.52 \pm 0.06^{\mathrm{c}}$ \\
\hline \multirow{2}{*}{ Cobalt } & $\mathrm{BDL}$ & $\mathrm{BDL}$ & $\mathrm{BDL}$ & $\mathrm{BDL}$ \\
\hline \multirow{2}{*}{ Lead } & & & & \\
& $(0.005-0.014)$ & $(0.01-0.02)$ & & $(0.008-0.013)$ \\
Cadmium & $0.01 \pm 0.00^{\mathrm{a}}$ & $0.01 \pm 0.00^{\mathrm{a}}$ & & $0.01 \pm 0.00^{\mathrm{a}}$ \\
\hline
\end{tabular}

Keys: Range (in brackets); Mean \pm Standard Error; BDL =below detection limit;Values with different superscript across row are significantly different at $(\mathrm{P}<0.05)$.

phosphate, $\mathrm{pH} 6.5$, containing $0.1 \%$ Triton X-100) and $20 \mathrm{lL}$ of glutathione. A background or nonenzymatic control was run by adding only $170 \mathrm{lL}$ of assay buffer and $20 \mathrm{lL}$ of glutathione to three wells. The reaction was initiated by adding $10 \mathrm{lL}$ of 1-chloro-2,4-dinitrobenzene (CDNB) and carefully shaken for several seconds. The absorbance was measured at $340 \mathrm{~nm}$ every $30 \mathrm{~s}$ for $10 \mathrm{~min}$ using a BioTek PowerwaveTM micro- plate reader. The rate of absorbance per min was determined for the background wells and subtracted from the sample wells. GST activity ( $\mathrm{nmol} / \mathrm{min} / \mathrm{mL}$ ) was normalized to protein, and final GST results reported as $\mathrm{nmol} / \mathrm{min} / \mathrm{mg}$ protein.

\section{Statistical Analysis}

Statistical analyses were carried out using SPSS version 17. Data were tested using Analysis of Variance (ANOVA) and Duncan Multiple Range Test (DMRT) at a level of significance of alpha of $5 \%(\alpha=0.05)$ to determine if the means are statistically significant among the four different crab species.

\section{Results and Discussions}

Heavy metal concentrations in crab tissues

With the importance of a healthy environment to the survival of aquatic organisms; their inherent capacity to reproduce, develop and growth could be massively affected in environments strained by external pressures (Ochang et al., 2007; LawalAre et al. 2018; Moruf and Lawal-Are, 2018). The presence of pollutant; measured as the relative concentration of heavy metals found in the tissue of the crabs showed slight variations (Table 1). Amongst all the measured heavy metal, cadmium concentration was the highest and significant $(\mathrm{P}<0.05)$ across species, ranging from $0.42 \pm 0.12 \mathrm{mg} / \mathrm{kg}$ (G.pelli) to $0.79 \pm 0.06 \mathrm{mg} /$ $\mathrm{kg}$ (C.armatum), followed by zinc and copper with concentrations of $0.41 \pm 0.01 \mathrm{mg} / \mathrm{kg}$ (P.validus)to $0.53 \pm 0.06 \mathrm{mg} / \mathrm{kg}$ (C.armatum) and $0.22 \pm 0.06 \mathrm{mg} /$ $\mathrm{kg}$ (C.amnicola) to $0.52 \pm 0.06 \mathrm{mg} / \mathrm{kg}$ (P. validus) respectively. However, lead concentration was relatively low, averaging $0.01 \pm 0.00 \mathrm{mg} / \mathrm{kg}$ across samples, while cobalt was largely below detection level. In respect to the organisms, heavy metals were more abundance in the $C$. armatum and recorded the lowest in G.pelli.

From the heavy metal result, the levels of metal pollution is mild, and in some cases negligible. However, metals such as zinc and copper were modest, showing minimal episode of heavy metal infusion to the adjoining water channel where these organisms dwell. There are many earlier surveys on effects of heavy metals on aquatic animals. Pan et al. (2011) have reported that heavy metal ions' $\left(\mathrm{Cu}^{2+}, \mathrm{Pb}^{2+}\right.$, and $\left.\mathrm{Cd}^{2+}\right)$ exposure caused DNA damage in haemocytes of marine crab Charybdis 
japonica. In freshwater crab Sinopotamon yangtsekiense, the mobilization of carbohydrate and protein was increased by cadmium stress (Xuan et al.,2011). Uncharacteristically, cadmium was recorded to be highest relative to the other heavy metals. This comes as a surprise given the almost traced nature of the cadmium in several literature studies in the particular environment where the crab species were caught (Edokpayi and Nkwoji, 2007). Contrary to the report of LawalAre and Babaranti (2014), where cadmium was the least abundant metal recorded in the smooth swim crab (P. validus) with the value of $0.42 \mathrm{mg} /$ $\mathrm{kg}$. The highest copper concentration observed in $P$. validus than all other species could be attributed to biological bioaccumulation process and the fact that benthic organisms are highly sensitive to environmental stress such as trace metal pollution (Ajao and Fagade, 1990; Moruf and Akinjogunla, 2018). According to Elghobashy et al., (2001), bioaccumulation of heavy metals in crustaceans critically influences the growth rate, physiological and biochemical status. Furthermore, a number of deleterious effects including oxidative stress from heavy metals bioaccumulation in biological systems have been reported by some researchers (Farombi et al., 2007; Soundararajan et al., 2009; Usese et al., 2018).

\section{Assessment of oxidative stress in crab tissues}

Biochemical enzymes activities in tissues of the crabs (Table 2) under study showed slight organismal variation with PRO ranging from $12.35 \pm 0.02 \mathrm{~g} / \mathrm{l}$ in C.armatum to $19.23 \pm 1.80 \mathrm{~g} / \mathrm{l}$ in C.amnicola. P.validus recorded a mean concentration as low as $14.81 \pm 1.23 \mathrm{~g} / \mathrm{l}$ while $G$. pelliwas $15.05 \pm 0.03 \mathrm{~g} / \mathrm{l}$. The lowest SOD activity was recorded in C. amnicola $(81.04 \pm 2.01 \mathrm{~min} / \mathrm{mg} /$ pro) and the highest in C. armatum (123.04 \pm 0.01 $\mathrm{min} / \mathrm{mg} / \mathrm{pro}$ ). Usese et al. (2018) also noted variations in the antioxidant response to oxidative stress in the various tissues of the Hairy Mangrove Crab, Sesarma huzardii from a tropical lagoon mudflat in southwest Nigeria. According to Viarengo et al. (1999), high SOD concentration suggests a correspondingly less polluted nature of the environment. As such, ROS activities should be low in the crab specimen because of the induced SOD that cleansed generated ROS spiked by heavy metal pollution.

Mean CAT activity in P.validus was $5.46 \pm 2.02$ $\mathrm{min} / \mathrm{mg} / \mathrm{pro}$ while C. armatum exhibited significant highest value of CAT $(\mathrm{P}<0.05)$ with mean activity of $7.74 \pm 0.05 \mathrm{~min} / \mathrm{mg} /$ pro closely followed by G. pelli ( $5.99 \pm 1.01 \mathrm{~min} / \mathrm{mg} / \mathrm{pro})$ with C. amnicola recording the lowest $(4.61 \pm 3.02 \mathrm{~min} /$ $\mathrm{mg} / \mathrm{pro}$ ).The low range of CAT activity might lead to less scavenging of excess hydrogen peroxide, if any exist in the cell membrane of the crab species. According to Pellerin-Massicotte (1997), catalase activity is considered as the primary defense against oxidative damage and has been well studied in marine invertebrates due to its ability to convert hydrogen peroxide into water.

The maximum significant concentration of GST was found in C. armicola with value of $18.21 \pm 0.02 \mathrm{Hmol} / \mathrm{mgpro}$ and the minimum was recorded in P.validus with value of $9.28 \pm 1.03 \mathrm{Hmol} /$

Table 2. Antioxidant enzyme activity in tissues of crab species

\begin{tabular}{lcccc}
\hline \multicolumn{1}{c}{ Biomarkers } & Goniopsis pelli & $\begin{array}{c}\text { Cardiosoma } \\
\text { armatum }\end{array}$ & $\begin{array}{c}\text { Callinectes } \\
\text { amnicola }\end{array}$ & Portonus validus \\
\hline PRO (g/l) & $15.05 \pm 0.03^{\mathrm{a}}$ & $12.35 \pm 0.02^{\mathrm{a}}$ & $19.23 \pm 1.80^{\mathrm{a}}$ & $14.81 \pm 1.23^{\mathrm{a}}$ \\
\hline SOD(min/mg/pro) & $107.89 \pm 0.02^{\mathrm{a}}$ & $123.04 \pm 0.01^{\mathrm{a}}$ & $81.04 \pm 2.01^{\mathrm{b}}$ & $88.63 \pm 1.41^{\mathrm{b}}$ \\
\hline CAT(min/mg/pro) & $5.99 \pm 1.01^{\mathrm{a}}$ & $7.74 \pm 0.05^{\mathrm{b}}$ & $4.61 \pm 3.02^{\mathrm{a}}$ & $5.46 \pm 2.02^{\mathrm{a}}$ \\
\hline GST(Hmol/mg pro) & $13.93 \pm 0.21^{\mathrm{a}}$ & $18.21 \pm 0.02^{\mathrm{b}}$ & $12.45 \pm 2.04^{\mathrm{a}}$ & $9.28 \pm 1.03^{\mathrm{c}}$ \\
\hline GSH(Hmol/mg pro) & $1.94 \pm 1.01^{\mathrm{a}}$ & $2.92 \pm 0.04^{\mathrm{a}}$ & $1.32 \pm 1.12^{\mathrm{a}}$ & $2.53 \pm 3.01^{\mathrm{a}}$ \\
\hline GPx(Hmol/mg pro) & $54.31 \pm 0.05^{\mathrm{a}}$ & $61.85 \pm 0.06^{\mathrm{b}}$ & $43.72 \pm 2.01^{\mathrm{a}}$ & $55.24 \pm 1.05^{\mathrm{a}}$ \\
\hline
\end{tabular}

Keys: PRO: Protein, SOD: Superoxide Dismutase, CAT: Catalase, GT: glutathione transferase, GSH: reduced glutathione, GPX: glutathione peroxidase (GPX) 
mg pro, significantly different from values obtained in other crab species. According to Fitzpatrick et al. (1997) and Hoarau et al. (2004), GST is regulated by a structurally diverse range of xenobiotics and at least 100 chemicals, including organochlorine compounds that have been identified to induce GST activity in marine invertebrate. In the present study, GSH was fairly low in concentration with value ranging from $1.32 \pm 1.12 \mathrm{Hmol} / \mathrm{mg}$ pro in C. amnicolato $2.92 \pm 0.04 \mathrm{Hmol} / \mathrm{mg}$ pro in C. armatum.GSH depletion suggested that the crabs might be suffering from oxidative damage (Chelomin et al., 2005; Ivanina et al., 2008). Average GPX activity was $55.74 \mathrm{Hmol} / \mathrm{mg}$ pro with slight species variation. According to Liu et al. (2014), with low concentration of heavy metal, GPx could protect membrane lipids from oxidative damage detoxifying the organic peroxides and act on organic hydroperoxides.

\section{Conclusion}

The presence of pollutant; measured as the relative concentration of heavy metals and the evaluated oxidative stress responses found in the tissue of the crabs suggests a correspondingly less polluted nature of the environment. With the positive conclusion of the ecological status of the crab, there should be a continue effort by environmental actors and stakeholder involved in coastal management in Nigeria in ensuring that the trend stay the same while further studies should proceed naturally from this back-end investigation.

\section{References}

1. Ajao EA, Fagade SO (1990). A study of the sediment and communities in Lagos Lagoon, Nigeria. Oil and Chemical Pollution, 7(2): 85- 117.

2. Akinjogunla VF, Moruf RO (2018). The ecology and growth biology of Farfantepenaeus notialis (Pérez-Farfante, 1967) from an open tidal estuary in Nigeria. Nigerian Journal of Fisheries, 15(1): 1326-1335

3. Akin-Oriola GM, Anetekhai MA, Olowonirejuaro K (2005). Morphometric and meristic studies in two crabs: Cardiosoma armatum and Callinectes pallidus. Turkish Journal of Fisheries and Aquatic Sciences, 5: 85-89.

4. Bertholdo-Vargas LR, Martins JN, Bordin D, Salvador M, Schafer AL, Barros NM, Barbieri L, Stirpe F, Carlini CR (2009). Type 1 ribosome-inactivating proteins Entomotoxic, oxidative and genotoxic action on Anticarsia gemmatalis (Hubner) and Spodopterafrugiperda (J.E. Smith) (Lepidoptera: Noctuidae).Journal of Insect Physiology, 55(1): 51-58.
5. Chelomin VP, Zakhartsev MV, Kurilenko AV, Belcheva NN (2005). An in vitro study of the effect of reactive oxygen species on subcellular distribution of deposited cadmium in digestive gland of mussel Crenomytilus grayanus. Aquatic Toxicology, 73: 181-189.

6. Cumberlidge $N$ (1999). The freshwater crabs of West Africa. Family Potamanautidae, Collection of fauna and flora in the Tropics (pp 236). Paris, IRD.

7. Depledge MH (1993). The rational basis for the use of biomarkers as ecotoxicological tools. In Fossi MC, Leonzio C (Eds.), Nondestructive Biomarkers in Vertebrates (pp. 261-285). Boca Raton, Lewis Publishers.

8. Don-Pedro KN, Oyewo EO, Otitoloju AA (2004). Trend of heavy metal concentrations in Lagos lagoon ecosystem, Nigeria. West African Journal of Applied Ecology, 5(1):103-114.

9. Edokpayi CA, Nkwoji JA (2007). Annual changes in the physicochemical and macrobenthic invertebrate's characteristics of the Lagos lagoon sewage dump site at Iddo, southern Nigeria. Ecology Environmentand Conservation, 13(1):13-18.

10. Elbekai RH, El-Kadi AO (2005). The role of oxidative stress in the modulation of aryl hydrocarbon receptorregulated genes by $\mathrm{As}^{3+}, \mathrm{Cd}^{2+}$, and $\mathrm{Cr}^{6+}$. Free Radical Biology \& Medicine, 39: 499-1511.

11. Elghobashy H, Khalid A, Zaghloul H, Mahmoud A, Metwally A (2001). Effect of some water pollutants on the Nile Tilapia, Oreochromis niloticus collected from the River Nile and some Egyptian lakes. Egyptian Journal of Aquatic Biology and Fisheries, 5(4): 251 - 219.

12. El-Khayat HM, Mahmoud KM, Gaber HS, Abdel-Hamidand H, Abu Taleb HM (2015). Studies on the effect of pollution on Lake Manzala ecosystem in Port-Said, Damietta and Dakahlia Governorates, Egypt. Journal of Egyptian Society of Parasitology, 45(1): 155-168.

13. Emmanuel BE, Chukwu LO, Bakare SO (2010). HydroChemistry, Macro-Invertebrate Fauna and Fish Production af Acadja Fishing Sites in a tropical Lagoona ecosystem. Journal of American Science, 6(1): 42-48.

14. Farombi EO, Adelowo OA, Ajimoko YR (2007). Biomarkers of oxidative stress and heavy metal levels as indicators of environmental pollution in African Cat Fish (Clarias gariepinus) from Nigeria Ogun River. International Journal of Environmental Research and Public Health, 4(2):158165.

15. Fitzpatrick PJ, O'Halloran J, Sheehan D, Walsh AR (1997). Assessment of a glutathione-S transferase and related proteins in the gill and digestive gland of Mytilus edulis (L), as potential organic pollution biomarkers. Biomarkers, 2: 51-56.

16. Frenzilli G, Nigro M, Scarcelli V, Gorbi S, Regoli F (2001). DNA integrity and total oxyradical scavenging capacity in the Mediterranean mussel, Mytilus galloprovincialis: a field study in a highly eutrophicated coastal lagoon. Aquatic Toxicology, 53: 19-32. 
17. Gadzała-Kopciuch R, Berecka B, Bartoszewicz J, Buszewski B (2004). Some considerations about bioindicators in environmental monitoring. Polish Journal of Environmental Study, 13(5): 453-462.

18. Hoarau P, Garello G, Gnassia-Barelli M, Roméo $M$, Girard JP (2004). Effect of three xenobiotic compounds on Glutathione $S$-Transferase in the clam Ruditapes decussatus. Aquat. Toxicology, 68: 87-94.

19. Ivanina AV, Cherkasov AS, Sokolova IM (2008). Effects of cadmium on cellular protein and glutathione synthesis and expression of stress proteins in eastern oysters, Crassostrea virginica Gmelin. The Journal of Experimental Biology, 211: 577-586.

20. Jebali J, Banni M, Boussetta H (2012). Biochemical biomarkers in aquatic ecotoxicology: fundamental mechanisms, application and perspectives. In Daniel J. A (Eds.), Advance in environmental research, Volume 23 (pp: 143-168), Nova Science Publisher, New York .

21. Lawal-Are AO, Babaranti OA (2014). Heavy metal concentrations in Pseudotolithus typus and Portunus validus, water and sediment from Tarkwa Bay, Nigeria. Nigerian Journal of Fisheries, 11 (1 and 2): 733-744.

22. Lawal-Are AO, Moruf RO, Alawode MM (2018). Haematobiochemial evaluation of mangrove crabs as a biomarker of environmental pollution in a tropical creek.13th UNILAG Annual Research Conference and Fair, 2th -30th, August, 2018.18SCI097.

23. Lawal-Are AO, Owolabi AT (2012). Comparative Biology of the Prawns M. macrobrachion (Herklots, 1851) and $M$. vollenhovenii (Herklots, 1857) from two interconnecting fresh/brackish water lagoons in South-West Nigeria. Journal of Marine Science Research and Development, 2: 108-116.

24. Liu N, Wang L, Yan B, LiY, Ye F, Li J,Wang Q (2014). Assessment of antioxidant defense system responses in the hepatopancreas of the freshwater crab Sinopotamon henanense exposed to lead. Hydrobiologia, 741: 3-12.

25. Lowry OH, Rosebrough NJ, Farr AL, Randall RJ (1951). Protein measurement with the Folin phenol reagent. The Journal of Biological Chemistry, 193: 265-275.

26. Lushchak VI, Bagnyukova TV, Huska VV, Luzhna LI, Lushchak OV, Storey KB (2005). Hyperoxia results in transient oxidative stress and an adaptive response by antioxidant enzymes in gold tissues. International Journal of Biochemistry and Cell biology, 37(8): 1670-1680.

27. Lykkesfeldt J (2007). Malondialdehyde as biomarker of oxidative damage to lipids caused by smoking. J. Clin. Chim Acta, 9: 31-50.

28. Maharajan A, Shanmugavel K (2015). Histological alterations of a combination of chlorpyrifos and cupermethrin (Nurocombi) insecticides in the fresh water crab, Paratelphulsa jacquemontiii (Rathbun). Journal of Basics and Applied Zoology, 72: 104-112.

29. Mandaville SM (2002). Benthic macro-invertebrates in freshwaters-taxa tolerance values, Metrics, and protocols project $\mathrm{H}-1$, soil and water conservation society of metro halifax. Synopses. http://chebucto.ca/Science/SWCS/ SWCS.html.

30. Martin-Diaz ML, Villena-Lincoln A, Bamber S, Blasco J, Del-Valls TA (2005). An integrated approach using bioaccumulation and biomarker measurements in female shore crab, Carcinus maenas. Chemosphere, 58: 615-626.

31. Moruf RO, Ojetayo TA (2017). Biology of the West African fiddler crab, Uca tangeri (Eydoux, 1835) (Decapoda: Ocypodidae) from a mangrove wetland in Lagos, Nigeria. International Journal of Aquatic Biology, 5 (4): 263-267.

32. Moruf RO, Akinjogunla VF (2018). Photometric determination of macro-micro minerals in the West African Mud Creeper, Tympanotonus fuscatus var radula (Linnaeus, 1758). Journal of Experimental Research, 6(3): 35- 40 .

33. Moruf RO, Lawal-Are AO (2018). Haemato-biochemical variations in estuarine crabs from a Lagoon Ecosystem. Journal of Applied Sciences and Environmental Management, 22(12): 1899 - 1903.

34. Ochang SN, Fagbenro OA, Adebayo OT (2007).Growth performance, Body composition, haematology and Product quality of the African Catfish (Clarias gariepinus) fed diets with Palm oil. Journal of Experimental Biology, 21: 83-93.

35. Pan LQ, Liu N, Zhang HX, Wang J, Miao JJ (2011). Effects of heavy metal ions $\left(\mathrm{Cu}^{2+}, \mathrm{Pb}^{2+}\right.$ and $\left.\mathrm{Cd}^{2+}\right)$ on DNA damage of the gills, haemocyte and hepatopancreas of marine crab. Journal of Ocean University of China (Oceanic and Coastal Sea Research), 10: 177-184.

36. Pellerin-Massicotte J (1997). Influence of elevated temperature and air-exposure on MDA levels and catalase activities in digestive glands of the blue mussel (Mytilus edulis L.). J.Rech. Océanogr., 22: 91-98.

37. Regoli F, Frenzilli G, Bocchetti R, Annarumma F, Scarcelli V, Fattorini D, Nigro M (2004). Time-course variations of oxyradical metabolism, DNA integrity and lysosomal stability in mussels, Mytilus galloprovincialis, during a field translocation experiment. Aquatic Toxicology, 68: 167-178.

38. Solarin BB, Udolisa RE, Omotayo NO, Lebo PE, Ambrose E (2003). Hook, line and sinker - the small scale fishing gear in Nigeria. ICSF Chennai, India/Brussels Belgium, Samudra, 35: $41-46$.

39. Soundararajan M, Veeraiyan G, Samipillai SS (2009). Arsenic-induced oxidative stress in fresh water tilapia (Tilapia mossambica). Journal of. Phytology, 1(4): 267276.

40. Suter GW (1990). Use of biomarkers in ecological risk assessment: McCarthy JF, Shugart LR (Eds.), Biomarkers of Environmental Contamination (pp. 419- 428) Boca Raton, FL, USA, Lewis Publishers.

41. Usese AI, Lawal-Are AO, Moruf RO, Chukwu LO (2018). Biomarker Responses to Environmental Stressors in the Hairy Mangrove Crab, Sesarma huzardi (Graspidae) from a tropical lagoon mudflat in Nigeria.Alexandria Journal of Veterinary Sciences, 57 (1): 4-10. 
42. Viarengo A, Burlando B, Dondero F, Marro A, Fabbri $R$ (1999). Metallothionein as a tool in biomonitoring programmes. Biomarkers, 4: 455-467.

43. Vijayavel K, GomathiRD,Durgabhavani K, Balasubramanian MP (2004). Sublethal effect of naphthalene on lipid peroxidation and antioxidant status in the edible marine crab Scylla serrata. Journal of Marine Pollution Bulletin, 48: 429-433.

44. Xuan RJ, Wang L, Sun M, Ren GR, Jiang ML (2011). Effects of cadmium on carbohydrate and protein metabolisms in the freshwater crab Sinopotamon yangtsekiense. Comparative Biochemistry and Physiology, 154: 268-274. 